\title{
COMPARATIVE STUDY OF DYDROGESTERONE AND NATURAL MICRONISED PROGESTERONE (NMP) IN THREATENED ABORTION
}

\section{Gynaecology}

Dr. Priti Singh*

Senior Resident, Dept. of Obs. and Gynae., JLN medical College, Bhagalpur 1.

*Corresponding Author

Dr. Krishna Sinha Associate Professor, Dept. of Obs. and Gynae., JLN medical College, Bhagalpur.

\section{ABSTRACT}

Progesterone is also called as propregnacy hormone. Threatened abortion is bleeding that occurs during first twenty weeks of pregnancy. A major step in management includes supplementation of progesterone for continuing pregnancy. It has been suggested that some women who experience spontaneous abortion may not be producing enough progesterone, so by administrating adjuvant progesterone it may be possible to prevent miscarriage. There are several formulations. In this study, we shall compare the efficacy of two form-the natural micronised progesterone \& dydrogestrone, a synthetic form in threatened abortion. An observational study was undertaken in O \& G department, JLN medical college, Bhagalpur for a period of one and half year. 50 women presented with either pain or bleeding PV within 12-20 wk of gestation. Each group of 25 given DYDR \& NMP. Serum progesterone was measured at one \&half month interval up to four\& half months. Usg fetal weight monitored on day $0 \& 135$.

\section{KEYWORDS}

\section{INTRODUCTION}

Progesterone has significant role in luteal phase support. Threatened abortion is bleeding that occurs during first twenty weeks of pregnancy. A major step in management includes supplementation of progesterone for continuing pregnancy. It has been suggested that some women who experience spontaneous abortion may not be producing enough progesterone. So adjuvant progesterone it added to prevent miscarriage. Progesterone is used in women with history of spontaneous preterm birth, in women with short cervix $(15 \mathrm{~mm})$, conception with assisted reproductive technique and women with threatened preterm labour. Older progesterones were having antigonadotropic actions, but newer progesterone have anti estrogenic, antimineralocorticoid, antiandrogenic actions. So they can be used extensively \& safely in first trimester, when fetus is more vulnerable for luteal phase insufficiency \&recurrent losses.

Progesterone act by various routes like oral, sublingual, topically, injectable, implants, vaginally, transdermally, nasal spray. Oral route is relatively ineffective as it is quickly metabolised in liver. Micronisation of naturalised progesterone made it possible to be used by oral route. Synthetic progesterones are also used. In this study, the efficacy of two form-the natural micronised progesterone \& dydrogestrone, a synthetic form in threatened abortion is compared.

\section{AIMAND OBJECTIVE}

To evaluate \&compare the efficacy of natural micronised progesterone $\&$ dydrogestrone in threatened abortion

\section{MATERIALAND METHOD}

This prospective observational study was carried out at JLN medical college, Bhagalpur for one and half year. Patients were selected considering inclusion \& exclusion criteria. Patients were advised bed rest. The serum progesterone levels are measured one \& half monthly upto four \& half months. The ultrasonographic fetal weight measured on day $0 \&$ at four and half months. Micronised progesterone used200mg OD \& dydrogestrone $-40 \mathrm{mg}$ immediately, then $10 \mathrm{mg}$ every 8 hrly till symptoms remit. All patients were taken for study were within gestational age 12-20wks. Increase in fetal weight was taken as parameter indicating improvement in patient condition. 50 pregnant women at gestational age upto 20 weeks who were referred due to threatened abortion. All study population was randomly divided into two equal groups. Group I (received Dydrogesterone tablet) and group II (received micronized Progesterone vaginally). Both were continued one week after stopping bleeding.

INCLUSION CRITERIA: All patients with clinical features suggestive of threatened abortion within 20 wks of gestation, having an ultrasound report that confirmed a viable fetus, no history of uterine anomalies and mullerian defects, having a closed cervical os, and no history of smoking and alcohol.

EXCLUSION CRITERIA: Patients with documented embryonic structural malformation, chromosomal aberrations, uterine anomaly, maternal hereditary thrombophilias, chronic medical illness such as hypertension, diabetes, severe hepatic impairment, antiphospholipid syndrome, fever, disorders of the cervix and cervical length are less than $3 \mathrm{~cm}$, allergy to components of prescribed drug, severe bleeding .

After history-taking and preliminary examinations, an ultrasound examination was performed for confirming a live fetus in the uterus; then patients received their treatment protocol according to their group. Data such as age, last menstruation age (LMP) and gestational age, history of previous pregnancies, the history for vaginal bleeding in previous pregnancies, the amount of vaginal bleeding, history of previous abortion, etc. were collected.

Complete obstetric history, medical \& surgical history, family \& personal history was taken. General examinations done. Clinical examinations of all the systems carried. Education \& socioeconomic status recorded. Referral status also recorded. Routine antenatal examination done. Serum progesterone on day 0 , one $\&$ half month, after 3 months, after four \& half months. Ultrasound feature for fetal weight at day $0 \&$ at four $\&$ half months noted.

\section{RESULT AND DISCUSSION}

25 patients studied with natural micronized progesterone and 25 patients studied with dydrogesterone. Both groups were matched for age. Maximum patients in both groups were between 20 to 30 years.

DYDROGESTERONE GROUP

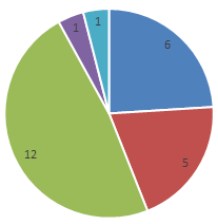

$\cdot 61 \cdot 62=63 \cdot 64=65$

NATURAL MICRONISED PROGESTERONE GROUP
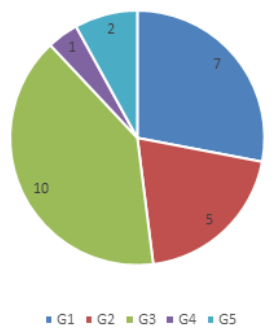

DISTRIBUTION OF PATIENTS IN BOTH GROUPS ACCORDING TO GRAVIDA 
After applying independent $t$ test for comparison of mean, $\mathrm{p}$ value 0.86 . Hence both the groups are not significantly different statistically in terms of gravida distribution.

DISTRIBUTION OF PATIENTS IN BOTH GROUPS ACCORDING TO GESTATIONALAGE

\begin{tabular}{|l|l|l|l|l|}
\hline GA & NMP & DYDR & TOTAL & PERCENTAGE \\
\hline $12-14$ & $10(40 \%)$ & $11(44 \%)$ & 21 & 42 \\
\hline $15-17$ & $9(36 \%)$ & $10(32 \%)$ & 17 & 34 \\
\hline $18-20$ & $6(24 \%)$ & $6(24 \%)$ & 12 & 24 \\
\hline TOTAL & 25 & 25 & 50 & 100 \\
\hline
\end{tabular}

After applying independent $t$ test for comparison of mean, $p$ value found to be 0.856 , no significant difference between two groups.
11 patients in NMP group presented with pain abdomen and 14 with bleeding per vaginum. While 13 patients in dydrogesterone group presented with pain abdomen and 12 with bleeding per vaginum.

Average value of serum progesterone on day 0 is $2.5 \mathrm{ng} / \mathrm{ml}$ in NMP group and $3.1 \mathrm{ng} / \mathrm{ml}$ in dydrogesterone group. Applying independent $\mathrm{t}$ test $p$ value 0.776 hence there is no significant difference between two groups.Average value of serum progesterone on day 45 is $25.5 \mathrm{ng} / \mathrm{ml}$ in NMP group and $19.6 \mathrm{ng} / \mathrm{ml}$ in dydrogesterone group. Average value of serum progesterone on day 90 is $78.5 \mathrm{ng} / \mathrm{ml}$ in NMP group and $59.6 \mathrm{ng} /$ $\mathrm{ml}$ in dydrogesterone group Average value of serum progesterone on day 135 is $125.5 \mathrm{ng} / \mathrm{ml}$ in NMP group and $99.6 \mathrm{ng} / \mathrm{ml}$ in dydrogesterone group. Applying independent t-test for comparison of mean, $\mathrm{t}$ value is found to be .79 as $\mathrm{df} 24$ with $\mathrm{p}$ value $=0.43$.so, there is significant difference between both groups.

\begin{tabular}{|l|l|l|l|l|l|l|l|l|l|}
\hline $\begin{array}{l}\text { Name of } \\
\text { drug }\end{array}$ & Mean value at day0 & Mean value at day 45 & Mean value at day 90 & Mean value at day 135 & T value & df & SD & N & P value \\
\hline NMP & $2.5 \pm 1.25$ & $25.5 \pm 9.3$ & $78.5 \pm 7.3$ & $125.5 \pm 10.4$ & 12.7 & 24 & 1.7 & 25 & $<0.001$ \\
\hline DYDR & $3.1 \pm 1.16$ & $19.6 \pm 7.8$ & $59.6 \pm 9.6$ & $99.6 \pm 7.9$ & 9.2 & 24 & 1.8 & 25 & 0.075 \\
\hline
\end{tabular}

After calculating \&comparing mean \& std deviation of each of the drug administered at day 0 , day 45 , day 90 , day 135 the $t$ value found to be statistically significant for NMP. In case of Dydrogesterone the increase in mean over period of time is not significant statistically.

Comparison of both groups as per usg fetal weight on day 0 in grams

\begin{tabular}{|c|c|c|c|c|c|}
\hline Drugs & $\begin{array}{c}\text { Mean Usg Fetal } \\
\text { Wt Gm }\end{array}$ & $\begin{array}{c}\text { Std. } \\
\text { Deviation }\end{array}$ & df & t value & P value \\
\hline NMP & 98.6 & 20.8 & 24 & 0.08 & 0.9 \\
\hline DYDR & 97.5 & 27.2 & & & \\
\hline
\end{tabular}

There is no significant difference between both the groups statistically according to day zero USG weight in grams

Comparison of both groups as per usg fetal weight on day 135 in grams

\begin{tabular}{|l|l|l|l|l|l|}
\hline Drugs & $\begin{array}{l}\text { Mean Usg Fetal } \\
\text { Wt Gm }\end{array}$ & Std Deviation & df & t value & p value \\
\hline NMP & 871.8 & 142.18 & 24 & 0.07 & 0.04 \\
\hline DYDR & 815.6 & 125.1 & & & \\
\hline
\end{tabular}

$\mathrm{p}$ value $=0.04$, hence there is significant difference between both the groups statistically according to 135 day usg fetal weight gm.

\section{SUMMARY \& CONCLUSION}

50 women presented with either pain or bleeding PV within 12-20 wk of gestation. Each group of 25 given Dydrogesterone \& NMP. Serum progesterone levels measured at one \&half monthly interval \& USG fetal weight at four \& half months compared with day 0 showed significantly better results in the group treated with NMP as compared with to Dydrogesterone.

\section{REFERENCES}

1. N, Sugiura-Ogasawara M. Genetic factors as a cause of miscarriage. Curr Med Chem. 2010;17:3431-7

2. Osmana ao lu MA, Erdo an I, Emina ao lu S, Karahan SC, Ozgün S, Can G. The diagnostic value of beta-human chorionic gonadotropin, progesterone, CA125 in the prediction of abortions. J Obstet Gynaecol. 2010;30:288-93

3. Aleman A, Althabe F, Belizan J, Bergel E. Bed rest during pregnancy for preventing Aleman A, Althabe F, Belizan J, Bergel E. Bed rest during p
miscarriage. Cochrane Database Syst Rev. 2005;2:CD003576

4. Qureshi NS, Edi-Osagie EC, Ogbo V, Ray S, Hopkins RE. First trimester threatened miscarriage treatment with human chorionic gonadotrophins: a randomised controlled trial. BJOG. 2005; 112(11): 1536-41.

5. Lede R, Duley L. Uterine muscle relaxant drugs for threatened miscarriage.Cochrane Database Syst Rev. 2005;3:CD002857. Goldstein P, Berrier J, Rosen S, Sacks HS, Chalmers TC. A meta-analysis of randomized control trials of progestational agents in pregnancy. Br J Obstet Gynaecol. 1989;96(3):265-74.

6. Omar MH, Mashita MK, Lim PS, Jamil MA. Dydrogesterone in threatened abortion: pregnancy outcome. J Steroid Biochem Mol Biol. 2005;97(5):421-5

7. Pandian RU. Dydrogesterone in threatened miscarriage: a Malaysian experience. Pandian RU. Dydrogesterone in the
Maturitas. 2009;65 Suppl 1:S47-50

8. El-Zibdeh MY, Yousef LT. Dydrogesterone support in threatened miscarriage.Maturitas. 2009;65 Suppl 1:S43-6.

9. Wahabi HA, Abed Althagafi NF, Elawad M, Al Zeidan RA. Progestogen for treating threatened miscarriage. Cochrane Database Syst Rev. 2011;3:CD005943.

10. Raghupathy R, Al Mutawa E, Makhseed M, Azizieh F, Szekeres-Bartho J. Modulation of cytokine production by dydrogesterone in lymphocytes from women with recurrent miscarriage. BJOG. 2005;112(8): 1096-101.

11. Blois SM, Joachim R, Kandil J, Margni R, Tometten M, Klapp BF, et al. Depletion of $\mathrm{CD} 8+$ cells abolishes the pregnancy protective effect of progesterone substitution with dydrogesterone in mice by altering the Th1/ Th2 cytokine profile. J Immunol. 2004;172(10):5893-9.

12. Joachim R, Zenclussen AC, Polgar B, Douglas AJ, Fest S, Knackstedt M, et al. The progesterone derivative dydrogesterone abrogates murine stresstriggered abortion by inducing a Th2 biased local immune response.Steroids. 2003;68(10-13):931-40. 